INOBIS: Jurnal Inovasi Bisnis dan Manajemen Indonesia

Volume 04, Nomor 02, Maret 2021

Celine Linardi, Triasesiarta Nur

\title{
Faktor-Faktor Yang Mempengaruhi Minat Mahasiswa Berdonasi Melalui Platform Crowdfunding
}

\author{
Celine Linardi \\ Fakultas Ekonomi dan Komunikasi Universitas Bina Nusantara \\ Triasesiarta Nur \\ Fakultas Ekonomi dan Komunikasi Universitas Bina Nusantara \\ *triasesiarta.nur@binus.ac.id
}

\begin{abstract}
Abstrak
Tujuan penelitian ini adalah untuk menjelaskan dan menganalisis pengaruh persepsi kegunaan, persepsi kemudahan, persepsi kepercayaan, dan norma subjektif terhadap minat mahasiswa berdonasi pada platform crowdfunding. Metode pengambilan sampel yang digunakan adalah metode non probability sampling. Responden dalam penelitian ini adalah mahasiswa/ mahasiswi yang berdomisili di Jabodetabek sebanyak 100 responden. Metode analisis yang digunakan dalam penelitian ini adalah regesi linear berganda. Hasil penelitian menunjukkan variabel persepsi kegunaan berpengaruh tidak signifikan terhadap minat mahasiswa berdonasi melalui platform crowdfunding. Sedangkan, persepsi kemudahan, kepercayaan, dan norma subjektif berpengaruh signifikan tehadap minat mahasiswa berdonasi melalui platform tersebut.
\end{abstract}

Kata Kunci: Crowdfunding, persepsi kegunaan, persepsi kemudahan, persepsi kepercayaan, norma subjektif, minat.

\section{Pendahuluan}

Data menunjukkan terjadinya pertumbuhan pada pengguna internet di Indonesia. Pengguna internet pada tahun 2018 sebanyak 95,2 juta pengguna, tumbuh 13,3\% dari 2017 yang sebanyak 84 juta pengguna. Pada periode 2018-2023 pengguna internet di Indonesia akan semakin meningkat dengan rata-rata pertumbuhan diperkirakan sebesar 10,2\%. Pada 2019 jumlah penggunaan internet di Indonesia tumbuh 12,6\% dibandingkan 2018, yaitu menjadi 107,2 juta pengguna. Pada 2023, jumlah penggunaan internet di Indonesia diproyeksikan mencapai 150 juta pengguna. Jika dilihat dari segi umur pengguna internet didominasi oleh milenial berusia 19-34 tahun. Pengguna internet didominasi oleh mahasiswa, dan pelajar jika dilihat dari pekerjaan. Jumlah pengguna internet terbanyak berada di Pulau Jawa jika dilihat dari lokasi. Mahasiswa yang termasuk dalam kategori milenial, sangat terekspos oleh pengaruh internet. Hal ini menyebabkan proses tumbuh kembang dari generasi tersebut akan bertumbuh bersama dengan internet (APJII, 2019).

Tidak dapat dipungkiri bahwa internet sudah sangat berjasa dalam memudahkan hidup manusia, terutama di kalangan mahasiswa. Dengan adanya internet, akses ke berbagai ilmu pengetahuan menjadi lebih mudah dan arus informasi yang datang dengan cepat. Peran internet sangat besar dalam menghadirkan generasi yang semakin pintar dan kritis. Dengan adanya internet, mahasiswa semakin mudah terpapar dengan informasi, budaya, dan ilmu dari seluruh 


\section{Celine Linardi, Triasesiarta Nur}

belahan dunia tanpa terkecuali. Proses belajar bisa lebih mudah dan praktis dengan adanya teknologi yang semakin maju ini.

Dalam beberapa dekade terakhir terjadi perkembangan teknologi yang begitu pesat, bermula sejak terjadinya revolusi industri 3.0 (ketiga) pada sekitar tahun 1990 hingga saat ini. Revolusi ini ditandai dengan ditemukannya internet, komputer, dan telepon genggam. Sejak saat itu terjadi perubahan yang besar dalam tananan industri, yang memiliki peran cukup besar dalam berbagai aspek kehidupan manusia. Teknologi digital membuat semuanya menjadi cepat dan mudah. Saat ini dunia sudah memasuki era globalisasi, dimana penyebaran informasi terjadi begitu cepat dan akses informasi yang sangat mudah, sehingga berbagai informasi dapat diperoleh dengan mudah dan tersebar secara real time ke seluruh dunia. Dengan adanya hal ini, waktu dan jarak bukanlah masalah yang berarti lagi dalam melakukan berbagai macam aktifitas di keseharian manusia. Di era yang maju ini, informasi menjadi aset yang penting dan menjadi komoditas yang sangat mahal. Informasi yang dimaksud adalah informasi dalam jumlah yang besar dan bila dianalisa dengan baik, maka dapat dimanfaatkan untuk berbagai tujuan secara efektif.

Akibat dari kemajuan teknologi ini, maka dalam perspektif ekonomi muncul istilah ekonomi digital sebagai sebuah konsep aktivitas ekonomi berbasis teknologi digital. Tapscott (1994) merupakan pencetus Ekonomi digital pertama di dunia. Tapscott menjelaskan tentang bagaimana teknologi dan strategi bisnis bertransformasi, mulai dari proses bisnis, cara produk dan jasa diproduksi dan dipasarkan, struktur dan tujuan perusahaan, juga dinamika dalam kompetisi bisnis. Sejauh ini ekonomi digital sangat dapat dirasakan dengan adanya sistem pembayaran elektronik (e-payment), perdagangan secara elektronik (e-commerce), hingga perbankan secara elektronik (e-banking). Industri yang kemudian mengalami disrupsi adalah industri jasa keuangan yang kemudian dikenal sebagai Teknologi Finansial / Financial Technology (fintech). Fintech mengacu pada perpaduan antara teknologi informasi dan jasa keuangan, yang merubah model bisnis dan kemudahan dalam memasuki industri.

Fintech (Financial Technology) merupakan inovasi di bidang jasa keuangan yang digabungkan dengan sentuhan teknologi. Fintech memberikan pengaruh kepada masyarakat secara luas dengan memberikan akses terhadap produk keuangan sehingga transaksi menjadi lebih efektif dan mudah.

Indonesia merupakan negara dengan tingkat peduli terhadap sesama tertinggi di dunia. Berdasarkan hasil survei yang dilakukan oleh Charity Aid Foundation (2018) dalam laporan tahunannya yang berjudul "CAF World Giving Index 2018: A Global View of Giving Trends", Indonesia dinobatkan sebagai negara terdermawan nomor 1 dari 144 negara di dunia dengan skor sebesar 59\%. Salah satu ukuran tingkat peduli pada survey tersebut adalah tentang "menolong" (Charities Aid Foundation, 2018). Terdapat 3 kategori menolong berdasarkan survei ini, yaitu menolong orang yang tidak dikenal, mendonasikan uang, dan total waktu dalam melakukan kegiatan sukarela. Skor Indonesia pada masing-masing kategori adalah sebesar $46 \%$ untuk menolong orang yang tidak dikenal, $78 \%$ untuk mendonasikan uang, dan $53 \%$ dalam total waktu dalam melakukan kegiatan sukarela. Pencapaian ini tentunya merupakan suatu kebanggaan besar mengingat pada tahun survei ini dibuat, Indonesia untuk pertama kalinya mendapat urutan pertama, setelah berada pada posisi kedua pada tahun 2017 . Hasil survei ini menunjukkan bahwa masyarakat Indonesia memiliki jiwa sosial yang cukup tinggi dan cenderung peduli terhadap lingkungan sekitar dengan cara membantu sesama, terutama secara finansial. Beberapa lembaga maupun perorangan membentuk berbagai komunitas, khusus untuk melakukan penggalangan dana.

Kegiatan penggalangan dana merupakan kegiatan sosial dalam mengumpulkan dana dari masyarakat secara sukarela. Saat ini, adanya akses internet yang tidak terbatas menjadi salah satu faktor yang mendukung kegiatan penggalangan dana dalam hal mempercepat 
penyebaran informasi mengenai aktivitas sosial yang sedang dilakukan. Akses internet juga digunakan sebagai sarana dalam penggalangan dana untuk mendukung suatu proyek atau pemberian jasa pada pihak yang membutuhkan. Kegiatan penggalangan dana ini disebut dengan Crowdfunding. Crowdfunding didefinisikan sebagai panggilan terbuka pada dasarnya melalui internet untuk penyediaan sumber daya keuangan baik dalam bentuk sumbangan atau sebagai imbalan atas beberapa bentuk hadiah atau hak suara untuk mendukung inisiatif untuk tujuan tertentu ((Schwienbacher \& Larralde, 2010). Kegiatan crowdfunding semakin banyak digunakan sebagai alternatif pembiayaan sebuah kegiatan. Proses pengumpulan dana dilakukan melalui platform, sehingga memungkinkan mereka yang membutuhkan dana untuk terhubung dengan funder dalam cakupan yang lebih luas. Platform ini merupakan website dimana founder mempromosikan proyek yang butuh didanai.

Perkembangan sistem Crowdfunding juga telah mengakar di Indonesia. Asal mula hadirnya Crowdfunding di Indonesia diawali dari kesadaran sosial masyarakat Indonesia untuk terlepas dari ketergantungan pembiayaan yang biasanya lebih dominan berbasis asing. Kesadaran ini dapat dilihat dari maraknya situs (platform) Crowdfunding yang mulai bermunculan dan berdampak positif bagi masyarakat Indonesia. Berikut ini adalah situs Crowdfunding aktif di Indonesia antara lain adalah Akseleran, Amrtha, Microfinance, CROWDO, DANAdidik, Gandeng Tangan, Investree, Kapi Boost, Koinworks, Kopernik, MEKAR Network, Modalku, Ko-fi, Patreon, Kickstarter, Kitabisa, dan AyoPeduli (Nugroho \& Rachmaniyah, 2019).

Untuk mengetahui faktor-faktor yang dapat meningkatkan minat untuk mengadopsi fintech crowdfunding, digunakan Technology Acceptance Model atau disingkat dengan TAM. TAM merupakan salah satu model yang paling banyak digunakan dan berpengaruh di dalam bidang sistem informasi, teknologi, dan layanan. TAM telah menjadi teori yang kuat sebagai kerangka kerja untuk memprediksi penerimaan pengguna teknologi baru. Model TAM dibangun dari beberapa variabel yakni : persepsi kegunaan, persepsi kemudahan, persepsi kepercayaan dan norma subjektif (Davis, 1989).

Berdasarkan latar belakang yang ada diatas, maka rumusan masalah pada penelitian ini, yaitu:

1. Apakah persepsi kegunaan berpengaruh terhadap minat mahasiswa berdonasi melalui platform Crowdfunding?

2. Apakah persepsi kemudahan berpengaruh terhadap minat mahasiswa berdonasi melalui platform Crowdfunding?

3. Apakah persepsi kepercayaan berpengaruh terhadap minat mahasiswa berdonasi melalui platform Crowdfunding?

4. Apakah norma subjektif berpengaruh terhadap minat mahasiswa berdonasi melalui platform Crowdfunding?.

\section{Landasan Teori dan Pengembangan Hipotesis}

Dalam konsep TAM, perceived usefulness atau persepsi kegunaan merupakan keyakinan akan kegunaan, yaitu tingkatan dimana seseorang percaya bahwa penggunaan teknologi tertentu akan meningkatkan performa mereka dalam mengerjakan suatu pekerjaan (Davis, 1989). Perceived usefulness merupakan sejauh mana seseorang memiliki keyakinan bahwa penggunaan sistem informasi akan meningkatkan kinerja. Persepsi kegunaan merupakan sistem yang berkaitan dengan produktifitas dan efektifitas sistem dari kegunaan dalam tugas secara menyeluruh untuk meningkatkan kinerja orang yang menggunakan sistem tersebut. Semakin kuat persepsi seseorang mengenai kegunaan suatu teknologi maka semakin besar minatnya untuk mengadopsi teknologi tersebut. 


\section{Celine Linardi, Triasesiarta Nur}

Perceived ease of use atau persepsi kemudahan merupakan tingkat keyakinan seseorang bahwa menggunakan suatu teknologi akan mempermudah aktivitasnya. Persepsi kemudahan penggunaan berarti keyakinan individu bahwa menggunakan sistem teknologi informasi tidak akan merepotkan atau membutuhkan usaha yang besar pada saat digunakan (Aeni \& Purwantini, 2017). Semakin kuat persepsi seseorang terhadap kemudahan penggunaan teknologi informasi tertentu, maka akan semakin kuat pula minatnya untuk menggunakan teknologi tersebut.

Theory of planned behavior (TPB) dikembangkan oleh Ajzen pada tahun 1988 serta merupakan pengembangan dari Theory of reasoned action (TRA). TPB dapat menjelaskan bahwa persepsi kepercayaan (Perceived Trust) dan norma subjektif (Subjective Norm) dapat mempengaruhi minat atau keinginan untuk menggunakan atau menerima teknologi. TPB banyak digunakan untuk menjelaskan variabel persepsi kepercayaan serta norma subjektif.

Perceived Trust atau persepsi kepercayaan menggambarkan suatu pengakuan antara dua belah pihak yang akan melakukan transaksi, apabila perceived trust diabaikan maka menjadi faktor yang akan memperlambat suatu transaksi yang akan dilakukan. Kepercayaan juga dapat dikatakan suatu kesediaan nasabah dengan segala ketentuan resiko yang ada (Rahmad \& Astuti, 2017). Kepercayaan memainkan peran penting dalam banyak interaksi sosial dan ekonomi seperti crowdfunding yang melibatkan ketidakpastian dan ketergantungan (Yu, Balaji, \& Khong, 2015). Semakin tinggi persepsi kepercayaan orang terhadap keandalan suatu teknologi maka akan semakin tinggi pula minatnya untuk mengadopsi teknologi tersebut.

Subjective Norm atau norma subjektif merupakan faktor sosial yang menunjukkan tekanan sosial yang dirasakan untuk melakukan atau tidak melakukan suatu perbuatan karena adanya persepsi dari orang lain yang menyatakan dukungan atau tidak, dalam hal ini dukungan terhadap pengadopsian teknologi tertentu. (Samudra, Maslichah, \& Sudaryanti, 2020). Semakin tinggi norma - norma sosial di lingkungan masyarakat dalam penggunaan teknologi informasi, maka akan semakin kuat pula minatnya untuk menggunakan teknologi tersebut.

\section{Financial Technology}

Financial Technology (Fintech) merupakan akronim dari penggalan kata 'finance' dan 'technology', yaitu inovasi di suatu kegiatan yang menyangkut tentang keuangan. Inovasi yang ditawarkan menyebar ke segala peran, mulai dari B2B (Business-to-Business) hingga B2C (Business-to-Customer). Definisi Fintech menurut (OJK, 2017) adalah sebuah inovasi pada industri jasa keuangan yang memanfaatkan penggunaan teknologi. Produk Fintech biasanya berupa suatu sistem yang dibangun guna menjalankan mekanisme transaksi keuangan yang spesifik.

Financial technology menjadi landasan baru bagi perekonomian dengan menjanjikan 3 hal. Pertama, fintech menawarkan produk dan solusi baru yang sebelumnya sulit dilakukan oleh layanan jasa keuangan. Kedua, fintech memberikan peluang dengan konsep dan penerapan teknologi yang baru, serta memiliki sifat yang dinamis dan sesuai dengan ranah keuangan yang diharuskan untuk selalu berinovasi dan dituntut melayani konsumen secara tepat dan akurat (Gomber \& Koch, 2017). Financial technology juga memberikan kemudahan bagi perusahaan dalam berkomunikasi, menjanjikan model bisnis baru, lebih fleksibel, keamanan, efisiensi, dan peluang dalam layanan keuangan (Lee \& Teo, 2015).

Menurut OJK, jenis-jenis perusahaan Fintech yang berkembang di Indonesia adalah sebagai berikut:

a. Digital Payment

Perusahaan Fintech Digital Payment memberikan layanan berupa pembayaran transaksi secara online sehingga proses tersebut menjadi lebih praktis, cepat, dan murah. 
INOBIS: Jurnal Inovasi Bisnis dan Manajemen Indonesia

Volume 04, Nomor 02, Maret 2021

Celine Linardi, Triasesiarta Nur

b. Financing and Investment

Perusahaan Fintech Financing and Investment meliputi perusahaan Fintech yang memberikan layanan Crowdfunding dan Peer-to-Peer Lending (P2P Lending).

c. Account Aggregator

Perusahaan Fintech dengan jenis Account Aggregator memberikan layanan yang dapat mengakomodasikan kebutuhan konsumen yang memerlukan dan menggunakan layanan transaksi dari beragam akun perbankan melalui 1 platform saja. Pengguna platform ini diberikan kemudahan dalam melakukan verifikasi transaksi karena prosesnya cepat dan singkat.

d. Personal Finance

Perusahaan Fintech Personal Finance mengakomodasi kebutuhan masyarakat akan perencanaan keuangan. Perusahaan ini, melalui platform-nya dapat membantu konsumen dari mulai pembuatan laporan keuangan yang baik hingga pemilihan pengolahan dana yang bijaksana.

\section{Crowdfunding}

Crowdfunding merupakan metode pendanaan berbasis internet untuk merealisasikan inisiatif, ide atau proyek melalui kontribusi yang didistribusikan secara online, dengan jumlah nominal yang tidak terlalu besar dalam kurun waktu yang terbatas. Pembiayaan ide atau proyek dilakukan melalui panggilan terbuka dengan menggunakan media Internet. Terdapat beberapa alternatif bagi pemberi dana untuk menyumbang, yakni dalam bentuk: uang, pre-order, pinjaman atau investasi berdasarkan keyakinan mereka terhadap janji, dan/atau ekspektasi mendapatkan tingkat return tertentu (Hossain \& Oparaocha, 2017).

Crowdfunding didefinisikan sebagai panggilan terbuka pada dasarnya melalui internet untuk penyediaan sumber daya keuangan baik dalam bentuk sumbangan atau sebagai imbalan atas beberapa bentuk hadiah atau hak suara untuk mendukung inisiatif untuk tujuan tertentu (Schwienbacher \& Larralde, 2010). Kegiatan crowdfunding semakin banyak digunakan sebagai alternatif pembiayaan sebuah kegiatan. Proses pengumpulan dana dilakukan melalui platform, sehingga memungkinkan mereka yang membutuhkan dana untuk terhubung dengan funder dalam cakupan yang lebih luas. Platform ini merupakan website dimana founder mempromosikan proyek yang butuh didanai.

Sementara itu, OJK menjelaskan Fintech Crowdfunding pada umumnya merupakan metode penghimpunan dana untuk suatu proyek maupun untuk penggalangan dana sosial. Dalam mekanismenya, perusahaan akan menampilkan proposal suatu proyek, usaha, event, atau kegiatan sosial yang diusulkan oleh seseorang atau suatu pihak melalui website atau aplikasi perusahaan Fintech Crowdfunding tersebut. Perusahaan Fintech akan mengundang pihak lain untuk menjadi investor atau pemberi dana. Investor atau pemberi dana tersebut akan melakukan transfer dana kepada rekening perusahaan untuk kemudian disalurkan kepada pihak yang mengajukan (OJK, 2017).

\section{Crowdfunding di Indonesia}

Startup crowdfunding lokal sudah mulai bermunculan di Indonesia sejak tahun 2012. Contoh yang paling dikenal antara lain seperti KitaBisa dan Ayo Peduli. KitaBisa merupakan platform crowdfunding untuk proyek sosial, KitaBisa juga terbuka untuk memfasilitasi proyek lain seperti teknologi, kreativitas, dan bisnis. Platform crowdfunding ini melakukan validasi terlebih dahulu pada setiap proyek sebelum akhirnya diterbitkan. Bahkan pihak KitaBisa mewajibkan founder proyek untuk mengirimkan laporan keuangan dan kemajuan 
perkembangan proyeknya. KitaBisa melakukan monetisasi dengan mengambil potongan sebesar 5\% dari setiap proyek yang berhasil terwujud. Proyek penggalangan dana dengan nilai terbesar yang berhasil diraih melalui KitaBisa sebesar Rp 3,2 pada tahun 2016 untuk penggalangan Masjid Chiba yang diprakarsai oleh komunitas muslim Indonesia di Chiba Jepang, di mana menggalang dana (Nugroho \& Rachmaniyah, 2019).

Ayo Peduli merupakan platform crowdfunding yang juga dikhususkan untuk kegiatan social, sama seperti KitaBisa. Proyek kegiatan sosial yang diterima Ayo Peduli dibagi menjadi tiga bagian, yaitu kesehatan, pendidikan, dan lingkungan. Untuk kategori pendidikan contohnya seperti, aksi sosial yang bisa dilakukan meliputi pengadaan perlengkapan sekolah, beasiswa, hingga kegiatan belajar mengajar. Cara kerja AyoPeduli sama seperti crowdfunding pada umumnya dimana founder bisa mendaftarkan proyeknya dengan mengisi formulir pendaftaran. Nantinya, proyek yang didaftarkan tersebut akan divalidasi oleh tim AyoPeduli berdasarkan tiga kriteria: Social Oriented (bersifat sosial), Social Impact (memiliki dampak sosial), dan valid (memiliki data yang nyata dan bukan rekayasa). Proyek penggalangan dana dengan nilai terbesar yang berhasil diraih melalui Ayo Peduli adalah Rumah Harapan dengan total Rp20 juta (Nugroho \& Rachmaniyah, 2019).

\section{Minat}

Menurut (Davis, 1989) menyebutkan bahwa minat perilaku didefinisikan sebagai tingkat seberapa kuat minat seseorang untuk melakukan perilaku tertentu. Minat perilaku adalah keinginan untuk melakukan perilaku. Minat berperilaku merupakan minat (keinginan) seseorang untuk melakukan sesuatu, seseorang dapat melakukan sesuatu apabila terdapat minat atau keinginan untuk melakukan sesuatu. Apabila dalam konteks penggunaan sistem informasi perilaku (behaviour) merupakan penggunaan sesungguhnya (actual usage) dari teknologi tersebut. Berhasil atau tidaknya suatu teknologi yang dikembangkan untuk meningkatkan pelayanan bergantung dari para penggunanya. Suatu teknologi akan berhasil jika penggunanya semakin banyak jumlahnya serta terus digunakan. Maka oleh karena itu, minat seseorang untuk menggunakan teknologi menjadi faktor penting (Ahmad \& Pambudi, 2014).

Pengukuran variabel minat berdasarkan penelitian (Priambodo \& Prabawani, 2016) dibagi menjadi 3:

a. Tertarik untuk menggunakan platform crowdfunding;

b. Keinginan menggunakan platform crowdfunding di masa depan

c. Mencari informasi mengenai platform crowdfunding

\section{Persepsi Kegunaan}

Persepsi Kegunaan merupakan sejauh mana seseorang percaya bahwa menggunakan suatu teknologi akan meningkatkan kinerja dari pekerjaannya (Chuang, Liu, \& Kao, 2016). Minat seseorang dalam menggunakan teknologi menjadi faktor yang penting. Berhasil atau tidaknya suatu teknologi yang dikembangkan untuk meningkatkan kualitas layanan sangat bergantung pada penggunanya. Suatu teknologi akan berhasil jika mengalami kenaikan jumlah penggunanya serta terus digunakan(Ahmad \& Pambudi, 2014). Dari definisi ini bisa diartikan bahwa adanya kegunaan dari fasilitas platform crowdfunding akan mampu meningkatkan produktivitas kinerja bagi orang yang menggunakan fasilitas tersebut. 


\section{Celine Linardi, Triasesiarta Nur}

Persepsi kegunaan berdasarkan penelitian (Chuang et al., 2016) terbagi menjadi 3 unsur, yaitu:

a. Platform crowdfunding memberikan manfaat berdonasi

b. Menggunakan platform crowdfunding meningkatkan kinerja proyek crowdfunding yang sedang berjalan

c. Menggunakan platform crowdfunding meningkatkan produktivitas berdonasi

\section{Persepsi Kemudahan}

Persepsi kemudahan penggunaan (Perceived ease of use) yaitu keyakinan seseorang bahwa menggunakan sistem teknologi informasi tidak akan membutuhkan usaha yang besar dan juga tidak merepotkan pada saat penggunaan (Aeni \& Purwantini, 2017). Faktor dalam persepsi kemudahan untuk menggunakan teknologi dan persepsi terhadap daya guna sebuah teknologi informasi yang berhubungan dengan sikap seseorang pada penggunaan teknologi tersebut jika penggunaan adalah sikap suka maupun tidak suka terhadap penggunaan suatu produk atau layanan, sikap tersebut dapat digunakan untuk memprediksi perilaku dan minat seseorang untuk menggunakan atau tidak suatu produk atau layanan (Ahmad \& Pambudi, 2014).

Persepsi kemudahan berdasarkan penelitian (Aeni \& Purwantini, 2017) terbagi menjadi 4 unsur, yaitu:

a. Mudah untuk mempelajari platform crowdfunding

b. Platform crowdfunding mudah ditemukan untuk melakukan kegiatan crowdfunding

c. Mudah untuk mengingat cara menggunakan platform crowdfunding

d. Interaksi dengan platform crowdfunding sangat jelas dan mudah dimengerti

\section{Pesepsi Kepercayaan}

Menurut (Tjini \& Baridwan, 2013), persepsi kepercayaan (Perceive of Trust) adalah kesediaan seseorang untuk menggantungkan dirinya pada pihak lain dengan risiko tertentu. Persepsi kepercayaan dalam penelitian ini adalah kesediaan para pengguna platform crowdfunding dengan segala resiko yang ada.

Pengukuran variable persepsi kepercayaan didasarkan pada penelitian (Moysidou \& Hausberg, 2020) yang terdiri dari 5 indikator:

a. Proyek crowdfunding yang diadakan dapat dipercaya

b. Pendanaan menggunakan platform crowdfunding memudahkan pembuat kampanye yang membutuhkan donasi.

c. Proyek crowdfunding yang diadakan sesuai dengan deskripsi yang diberikan.

d. Proyek crowdfunding yang diadakan sesuai dengan kententuan yang diberikan.

e. Pendanaan melalui proyek crowdfunding tidak akan disalahgunakan.

\section{Norma Subjektif}

(Mas'ud, 2012) menyatakan bahwa Norma subyektif (subjective norms) adalah pengaruh sosial yang mempengaruhi seseorang untuk berperilaku terhadap sikap tertentu. Seseorang akan memiliki keinginan terhadap suatu obyek atau perilaku apabila individu tersebut terpengaruh oleh orang-orang di sekitarnya untuk melakukannya atau meyakini bahwa lingkungan atau orang-orang disekitarnya mendukung terhadap apa yang lakukan.

Norma subjektif di sisi lain, didefinisikan sebagai penilaian seseorang terhadap kondisi pendukung yang penting bagi orang tersebut menyetujui atau tidak menyetujui perilaku yang 
akan dilakukan atau dengan kata lain adanya pengaruh tekanan sosial yang dialami seseorang untuk melaksanakan perilaku tertentu (Sari, 2019).

Pengukuran variable norma subjektif didasarkan pada penelitian (Y Chen, Dai, Yao, \& $\mathrm{Li}, 2019)$ yang terdiri dari 4 indikator:

a. Pengaruh orang untuk melakukan donasi proyek crowdfunding.

b. Dukungan keluarga untuk melakukan donasi proyek crowdfunding.

c. Dukungan teman untuk melakukan donasi proyek crowdfunding.

d. Pemerintah secara aktif mendukung penggunaan platform crowdfunding untuk membantu orang lain yang membutuhkan.

\section{Pengembangan Hipotesis}

\section{Pengaruh Persepsi Kegunaan terhadap Minat Berdonasi Pada Platform Crowdfunding}

Persepsi Kegunaan (perceived usefulness) salah satu bagian dari teori TAM yang menyatakan seseorang percaya bahwa penggunaan suatu teknologi tertentu akan meningkatkan kinerja dari individu. Persepsi Kegunaan dalam TAM bertujuan untuk menjelaskan dan memperkirakan penerimaan (acceptance) pengguna terhadap suatu sistem informasi. Dalam konteks Fintech persepsi kegunaan didefinisikan sebagai sejauh mana Fintech dapat memberikan manfaat bagi penggunanya dalam meningkatkan produktivitas dan kinerja pada saat penggunaan teknologi (Novitasari, 2016). Hasil penelitian yang dilakukan oleh (Jaziri \& Miralam, 2019) menyatakan bahwa persepsi kegunaan berpengaruh signifikan dalam minat menggunakan platform crowdfunding karena dapat memberikan layanan kegunaan seperti: memberikan pendanaan lebih cepat, kinerja, peningkatan produktivitas, efektivitas, dan mempermudah pengumpulan dana. Persepsi kegunaan juga dapat memengaruhi minat dan perilaku seseorang dalam menggunakan platform crowdfunding. Berdasarkan uraian diatas maka dapat disimpulkan:

\section{$\mathrm{H}_{1}$ : Persepsi Kegunaan berpengaruh signifikan terhadap Minat Berdonasi melalui Platform Crowdfunding}

\section{Pengaruh Persepsi Kemudahan terhadap Minat Berdonasi Menggunakan Platform Crowdfunding}

Persepsi kemudahan merupakan salah satu bagian dari teori TAM yang didefinisikan sebagai sejauh mana seseorang percaya bahwa menggunakan suatu teknologi akan bebas dari usaha. Dalam teori TAM, faktor persepsi kemudahan untuk menggunakan teknologi berhubungan dengan sikap seseorang pada penggunaan teknologi tersebut. Jika seseorang merasa percaya bahwa sistem informasi mudah digunakan maka dia akan menggunakannya. Sebaliknya, jika seseorang merasa percaya bahwa sistem informasi tidak mudah digunakan maka dia tidak akan menggunakannya. Persepsi kemudahan sudah terbukti menjadi determinan utama yang mempengaruhi minat dan kepercayaan seseorang dalam pengambilan keputusan untuk menggunakan berbagai teknologi. Pengguna akan berminat untuk menggunakan sebuah teknologi bila teknologi tersebut dianggap mudah digunakan (user-friendly) (Patel \& Patel, 2018). Hasil penelitian yang dilakukan oleh (Lacan \& Desmet, 2017) menyatakan bahwa ketika platform crowdfunding mudah digunakan (nilai persepsi kemudahan tinggi), maka semakin tinggi minat penggunaan dalam platform crowdfunding. Berdasarkan uraian diatas maka dapat disimpulkan: 
INOBIS: Jurnal Inovasi Bisnis dan Manajemen Indonesia

Volume 04, Nomor 02, Maret 2021

Celine Linardi, Triasesiarta Nur

\section{$\mathrm{H}_{2}$ : Persepsi Kemudahan berpengaruh signifikan terhadap Minat Berdonasi melalui Platform Crowdfunding}

\section{Pengaruh Persepsi Kepercayaan terhadap Minat Berdonasi Pada Platform Crowdfunding}

Persepsi kepercayaan salah satu bagian dari teori TPB yang didefinisikan sebagai kesediaan seseorang untuk menggantungkan dirinya pada pihak lain dengan risiko tertentu. Dalam teori TPB, persepsi kepercayaan secara khsusus menghubungkan antara beliefs atau keyakinan dengan sikap (attitudes). Seseorang akan mengevaluasi sikap terhadap seseorang lainnya yang ditentukan oleh aksesibilitas keyakinan mereka, dimana keyakinan merupakan probabalisitas subyektif bahwa perilaku akan berdampak pada sesuatu yang pasti. Persepsi kepercayaan dalam konteks crowdfunding adalah kredibilitas proyek crowdfunding sesuai penilaian para funder, sehingga ketika meninjau proyek crowdfunding, funder seringkali bergantung pada rasa kepercayaan yang diberikan oleh platform crowdfunding dan founder untuk memutuskan apakah mereka (funder) akan melakukan donasi ke proyek crowdfunding yang dipilih (Y Chen et al., 2019). Hasil penelitan yang dilakukan oleh (Sari, 2019) menyatakan bahwa persepsi kepercayaan berpengaruh signifikan terhadap keputusan berdonasi di platform crowdfunding KitaBisa. Berdasarkan uraian diatas maka dapat disimpulkan:

\section{$\mathrm{H}_{3}$ : Persepsi Kepercayaan berpengaruh signifikan terhadap Minat Berdonasi melalui Platform Crowdfunding.}

\section{Pengaruh Norma Subjektif terhadap Minat Berdonasi Pada Platform Crowdfunding}

Norma subjektif salah satu bagian dari teori TPB yang didefinisikan sebagai penilaian seseorang terhadap kondisi pendukung yang penting bagi orang tersebut menyetujui atau tidak menyetujui perilaku yang akan dilakukan. Dalam teori TPB, norma subjektif menjelaskan bahwa sikap terhadap perilaku merupakan pokok penting yang sanggup memperkirakan suatu perbuatan, meskipun demikian perlu dipertimbangkan sikap seseorang dalam menguji norma subjektif serta mengukur kontrol perilaku persepsian orang tersebut. Norma subjektif didasarkan pada pengaruh orang lain, seperti "teman", "keluarga", dan "kolega", yang dekat atau penting bagi orang tersebut. Norma subyektif menangkap perasaan individu tentang tekanan sosial dari suatu perilaku (Y Chen et al., 2019). Hasil penelitian yang dilakukan oleh (Shneor \& Munim, 2019) menyatakan bahwa norma subyektif secara positif mempengaruhi minat untuk berkontribusi crowdfunding dilihat dari sejauh mana seseorang bersedia berkontribusi dalam proyek crowdfunding, sejauh mana lingkungan sosial mereka mendorong mereka untuk melakukannya (norma subjektif), dan sejauh mana kontribusi orang lain untuk proyek crowdfunding meningkatkan kesediaan mereka untuk melakukan kontribusi. Berdasarkan uraian diatas maka dapat disimpulkan:

\section{H4: Norma Subjektif berpengaruh signifikan terhadap Minat Berdonasi Pada Platform Crowdfunding.}

Gambar berikut ini merupakan model penelitian : 


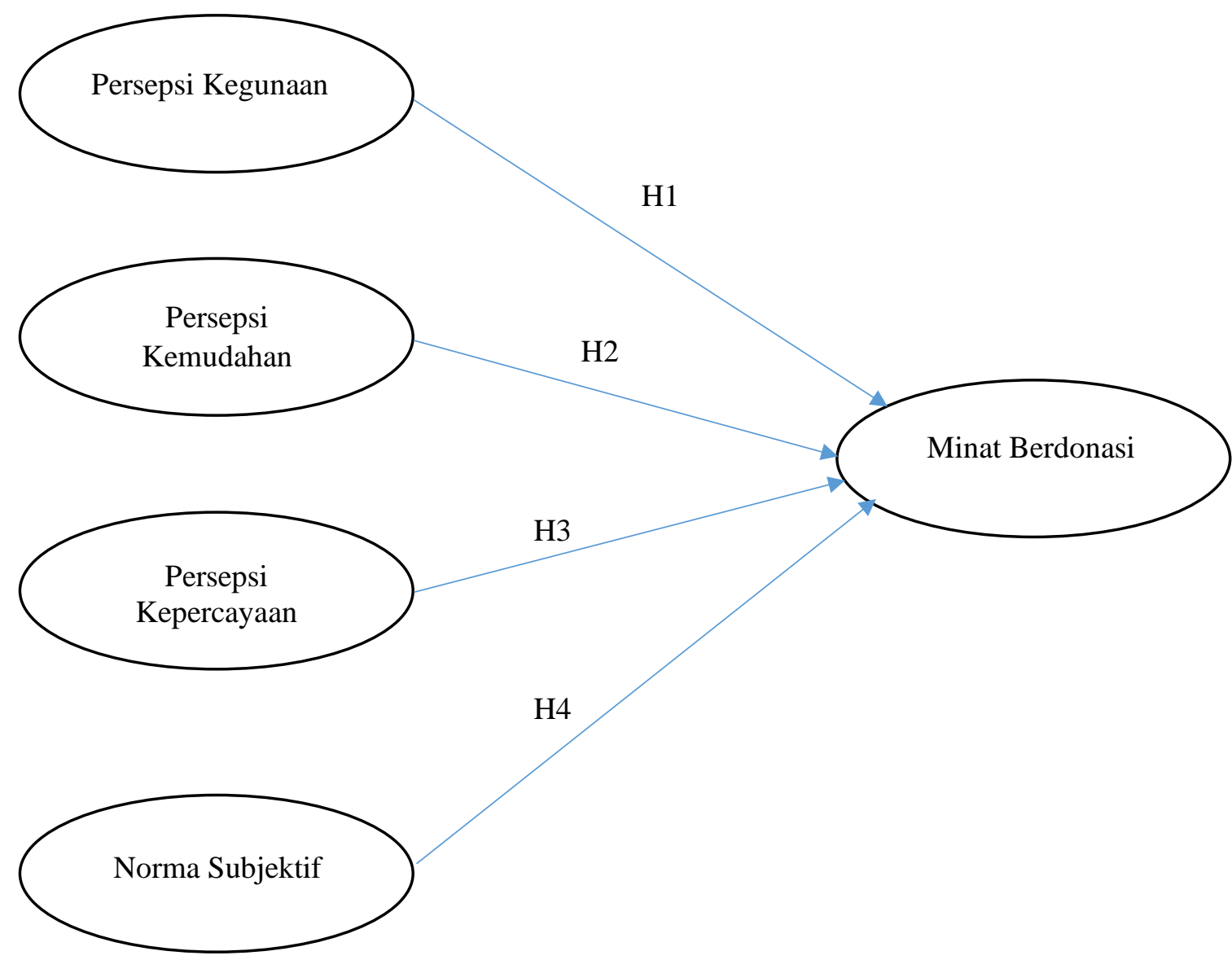

Gambar 1. Model Penelitian

\section{Metode Penelitian}

Penelitian ini menggunakan metode kuantitatif. Pendekatan kuantitatif adalah pendekatan dalam penelitian yang menggunakan data berupa angka-angka. Penelitian ini bertujuan untuk mengevalusai persepsi kegunaan, persepsi kemudahan, persepsi kepercayaan, dan norma subjektif terhadap minat penggunaan platform crowdfunding pada mahasiswa/mahasiswi yang berdomisili di Jabodetabek. Jenis penelitian ini merupakan penelitian sebab-akibat (causal research), yaitu penelitian yang dilakukan untuk menganalisis hubungan - hubungan antara satu variabel dengan variabel lainnya atau bagaimana suatu variabel mempengaruhi variabel lainnya. Konsep causal research didasarkan pada logika pengujian hipotesis yang menghasilkan kesimpulan induktif.

Penelitian ini menggunakan data primer yang didapatkan melalui penyebaran kuesioner kepada mahasiswa/mahasiswi yang berdomisili di Jabodetabek, secara spesifik pada mahasiswa/mahasiswi yang mengetahui platform crowdfunding sebagai sarana donasi. Sementara data sekunder diperoleh dari data penunjang melalui studi pustaka, jurnal, literatur, artikel media massa, dan buku yang berkaitan dengan topik penelitian ini.

Populasi adalah wilayah generalisasi yang terdiri atas: obyek atau subyek yang mempunyai kualitas dan karakteristik tertentu yang ditetapkan oleh peneliti untuk dipelajari dan kemudian ditarik kesimpulannya (Sugiyono, 2016). Populasi yang digunakan dalam penelitian ini adalah mahasiswa/mahasiswi yang berdomisili di Jabodetabek.Sampel adalah bagian dari jumlah dan karakteristik yang dimiliki oleh populasi tersebut. Metode pengambilan sampel dalam penelitian ini dengan pendekatan metode non-probability sampling dengan 
teknik pengambilan sampel purposive sampling. Teknik ini dipilih karena populasi dan sampel yang diambil memiliki karakteristik tertentu. Metode purposive sampling digunakan karena anggota-anggota yang dipilih menjadi bagian sampel dianggap dapat memberikan informasi yang dibutukan oleh peneliti. Purposive sampling dengan kata lain disebut judgement sampling yaitu metode yang yang digunakan peneliti karena informasi yang diambil berasal dari sumber yang dipilih berdasarkan kriteria tertentu, yang merupakan mahasiswa/mahasiswi yang berdomisili di Jabodetabek dan mengetahui adanya platform crowdfunding sebagai sarana donasi. Jumlah sampel yang dibutuhkan berdasarkan perhitungan rumus Lemeshow dikarenakan jumlah populasi tidak diketahui atau tidak terhingga minimal sebanyak 100 responden.

Metode pengumpulan data yang digunakan dalam penelitian ini adalah dengan menyebarkan kuesioner secara daring / online dengan menggunakan Google Form yang berisi daftar pertanyaan mengenai masalah yang diteliti kepada responden. Responden akan menjawab butir-butir pertanyaan dengan memilih salah satu pilihan jawaban yang tersedia dalam kuesioner. Kuesioner disebar kepada kelompok responden yang telah ditentukan oleh peneliti yaitu Mahasiswa/Mahasiswi yang berdomisili di Jabodetabek dan mengetahui adanya platform crowdfunding sebagai sarana donasi.

Dalam penelitian, kuesioner dibuat dengan menggunakan pertanyaan tertutup. Pengukuran variabel menggunakan skala interval, yaitu alat pengukuran variabel yang bernilai klasifikasi dan urutannya. Dalam penelitian ini, teknik yang dipakai dalam pengukuran kuesioner menggunakan agree-disagree scale. Skala yang digunakan untuk mengukur adalah skala dengan interval 1-5, dari sangat tidak setuju sampai sangat setuju. Pernyataan di berikan skor 1 untuk jawaban sangat tidak setuju, skor 2 untuk jawaban tidak setuju, skor 3 untuk jawaban netral, skor 4 untuk jawaban setuju, skor 5 untuk jawaban sangat setuju. Skala yang digunakan dalam penelitian ini disebut dengan skala likert. Skala likert digunakan untuk mengukur sikap, pendapat dan persepsi seseorang atau sekelompok orang tentang fenomena sosial. Skala likert juga termasuk dalam skala ordinal. Selain skala likert ada beberapa juga yang termasuk skala ordinal diantaranya Guttman, Diferensial Semantik, Peringkat (Rating), derajat (degree), dan tingkatan (level).

\section{Pembahasan}

\section{Uji Validitas}

Uji validitas digunakan untuk menguji keabsahan setiap item/ indikator dalam kuesioner sebagai alat ukur variable yang akan diteliti. Suatu item dapat dinyatakan valid atau berkolerasi signifikan terhadap skor total jika nilai $r$ hitung lebih besar daripada $r$ tabel.

Penelitian ini menggunakan uji validitas Korelasi Bivariate (Pearson) 2 arah dengan 100 sampel dengan degree of freedom $(\mathrm{df})=\mathrm{n}-2=100-2=98$ sehingga $\mathrm{r}$ tabel pada probabilitas $5 \%$ adalah 0.1654 . Berikut ini adalah hasil uji validitas:

Tabel 1. Hasil Perhitungan Uji Validitas

\begin{tabular}{|l|l|c|c|c|}
\hline \multirow{2}{*}{ Variabel } & Indikator & r hitung & r tabel & Keterangan \\
\hline \multirow{3}{*}{ Minat } & Minat 1 & 0.841 & 0.1654 & Valid \\
\cline { 2 - 5 } & Minat 2 & 0.819 & 0.1654 & Valid \\
\cline { 2 - 5 } & Minat 3 & 0.846 & 0.1654 & Valid \\
\hline \multirow{2}{*}{ Persepsi Kegunaan } & Kegunaan 1 & 0.728 & 0.1654 & Valid \\
\cline { 2 - 5 } & Kegunaan 2 & 0.783 & 0.1654 & Valid \\
\hline
\end{tabular}


INOBIS: Jurnal Inovasi Bisnis dan Manajemen Indonesia

Volume 04, Nomor 02, Maret 2021

Celine Linardi, Triasesiarta Nur

\begin{tabular}{|l|l|l|l|c|}
\hline & Kegunaan 3 & 0.746 & 0.1654 & Valid \\
\hline Persepsi Kemudahan & Kemudahan 1 & 0.789 & 0.1654 & Valid \\
\cline { 2 - 5 } & Kemudahan 2 & 0.846 & 0.1654 & Valid \\
\cline { 2 - 5 } & Kemudahan 3 & 0.803 & 0.1654 & Valid \\
\cline { 2 - 5 } & Kemudahan 4 & 0.771 & 0.1654 & Valid \\
\hline \multirow{4}{*}{ Kersepsi } & Kepercayaan 1 & 0.707 & 0.1654 & Valid \\
\cline { 2 - 5 } & Kepercayaan 2 & 0.771 & 0.1654 & Valid \\
\cline { 2 - 5 } & Kepercayaan 3 & 0.762 & 0.1654 & Valid \\
\cline { 2 - 5 } & Kepercayaan 4 & 0.731 & 0.1654 & Valid \\
\hline Norma Subjektif & Norma 1 & 0.749 & 0.1654 & Valid \\
\cline { 2 - 5 } & Norma 2 & 0.726 & 0.1654 & Valid \\
\cline { 2 - 5 } & Norma 3 & 0.776 & 0.1654 & Valid \\
\cline { 2 - 5 } & Norma 4 & 0.729 & 0.1654 & Valid \\
\hline
\end{tabular}

Sumber: Hasil Pengolahan Data

Tabel di atas menunjukkan bahwa setiap butir pertanyaan dari seluruh variabel memililiki kriteria valid. Artinya setiap indikator yang digunakan dalam kuisioner ini valid karena masing-masing nilai $r$ hitung memenuhi syarat, dimana $r$ hitung lebih besar daripada $r$ tabel.

\section{Uji Reliabilitas}

Suatu instrumen pengukuran (kuesioner) dikatakan reliabel bila memberikan hasil score yang konsisten pada setiap pengukuran. Suatu pengukuran mungkin reliabel tapi tidak valid, tetapi suatu pengukuran tidak bisa dikatakan valid bila tidak reliabel.

Metode pengujian reliabilitas instrumen menggunakan rumus korelasi Alpha Cronbach, dengan ketentuan nilai Alpha Cronbach > 0,60 dapat diterima. Tabel 2 Berikut adalah hasil uji reliabilitas:

Tabel 2. Hasil Perhitungan Uji Reabilitas

\begin{tabular}{|l|c|c|}
\hline \multicolumn{1}{|c|}{ Variabel } & Cronbach's Alpha & Keterangan \\
\hline Minat & 0.777 & Reliabel \\
\hline Persepsi Kegunaan & 0.613 & Reliabel \\
\hline Persepsi Kemudahan & 0.816 & Reliabel \\
\hline Persepsi Kepercayaan & 0.666 & Reliabel \\
\hline Norma Subjektif & 0.724 & Reliabel \\
\hline
\end{tabular}

Sumber: Hasil Pengolahan Data

Tabel di atas menunjukkan nilai Cronbach Alpha untuk seluruh variabel yang digunakan dalam penilitian ini adalah reliabel. Hal tersebut disimpulkan dari nilai Cronbach Alpha yang dihasilkan oleh setiap variabel lebih dari 0,6.

\section{Uji Asumsi Klasik}

Pengujian ini dilakukan untuk melihat apakah data yang digunakan untuk penelitian ini mengalami penyimpangan asumsi klasik atau tidak. Pada uji asumsi yang dilakukan tedapat 3 uji yang digunakan yaitu uji normalitas, uji multikolinieritas, dan uji heteroskedastisitas, dan uji autokoleritas. Hasil dari 4 uji yang digunakan adalah: 


\section{Uji Normalitas}

Tabel 3. Hasil Uji Normalitas

\begin{tabular}{|c|c|c|}
\hline \multicolumn{3}{|c|}{ One-Sample Kolmogorov-Smirnov Test } \\
\hline & & $\begin{array}{l}\text { Unstandardized } \\
\text { Residual }\end{array}$ \\
\hline \multicolumn{2}{|l|}{$\mathrm{N}$} & 100 \\
\hline \multirow{2}{*}{$\begin{array}{l}\text { Normal } \\
\text { Parameters }\end{array}$} & Mean & 0.0000000 \\
\hline & $\begin{array}{l}\text { Std. } \\
\text { Deviation }\end{array}$ & 1.77963243 \\
\hline \multirow{3}{*}{$\begin{array}{l}\text { Most Extreme } \\
\text { Differences }\end{array}$} & Absolute & 0.061 \\
\hline & Positive & 0.061 \\
\hline & Negative & -0.039 \\
\hline \multicolumn{2}{|l|}{ Test Statistic } & 0.061 \\
\hline \multicolumn{2}{|c|}{ Asymp. Sig. (2-tailed) } & $.200^{\mathrm{c}, \mathrm{d}}$ \\
\hline \multicolumn{3}{|c|}{ a. Test distribution is Normal. } \\
\hline \multicolumn{3}{|c|}{ b. Calculated from data. } \\
\hline \multicolumn{3}{|c|}{ c. Lilliefors Significance Correction. } \\
\hline \multicolumn{3}{|c|}{$\begin{array}{l}\mathrm{d} \text {. This is a lower bound of the true } \\
\text { significance. }\end{array}$} \\
\hline
\end{tabular}

Sumber: Hasil Pengolahan Data

Pengujian ini digunakan untuk mengetahui apakah variabel pengganggu atau residual dalam suatu model regresi berdistribusi normal atau tidak. Suatu model regresi seharusnya berdistribusi normal atau mendekatinya. Dalam hal ini uji normalitas data dilakukan dengan menggunakan pendekatan uji Kolmogorov. Uji normalitas dinyatakan berdistribusi normal jika nilai Asymp sig lebih besar daripada 0.05

Output yang dihasilkan dari data yang telah diinput menunjukkan bahwa nilai yang dihasilkan pada Asym. Sig sebesar 0,200. Yang dapat dikatakan lebih besar dari kriteria minimal, yaitu 0,05. Sehingga dapat disimpulkan bahwa nilai residual tersebut normal.

\section{Uji Multikolinearitas}

Pengujian ini digunakan untuk mengetahui adanya korelasi antar variabel independen. Suatu model regresi seharusnya tidak terdapat korelasi pada setiap variabel independennya. Metode ini dilakukan dengan menganalisis nilai Tolerance dan VIF. Multikolinearitas dinyatakan tidak terjadi jika nilai Tolerance lebih besar dari 0.1 dan nilai VIF lebih kecil dari 10.

Jika nilai tolerance pada variabel Persepsi Kegunaan (Perceived Usefulness), Persepsi Kemudahan (Perceived Ease of Use), dan Persepsi Kepercayaan (Perceived Trust), dan Norma Subjektif (Subjective Norm) > 0,10 maka tidak terjadi multikolinieritas, dan jika nilai VIF pada variabel Persepsi Kegunaan (Perceived Usefulness), Persepsi Kemudahan (Perceived Ease of Use), Persepsi Kepercayaan (Perceived Trust), dan Norma Subjektif (Subjective Norm) $<10,00$ maka tidak terjadi multikolineritas. Berikut adalah tabel rangkuman dari hasil perhitungan utuk uji multikolinearitas: 
Tabel 4. Hasil Uji Multikolinearitas

\begin{tabular}{|l|c|c|c|}
\hline \multirow{2}{*}{ Variabel } & \multicolumn{2}{|c|}{ Collinearity Statistics } & \multirow{2}{*}{ Keterangan } \\
\cline { 2 - 3 } & Tolerance & VIF & \\
\hline Persepsi Kegunaan & 0.632 & 1.582 & Tidak terjadi Multikolinearitas \\
\hline Persepsi Kemudahan & 0.668 & 1.497 & Tidak terjadi Multikolinearitas \\
\hline Persepsi Kepercayaan & 0.566 & 1.767 & Tidak terjadi Multikolinearitas \\
\hline Norma Subjektif & 0.951 & 1.051 & Tidak terjadi Multikolinearitas \\
\hline
\end{tabular}

Sumber: Hasil Pengolahan Data

\section{Uji Heterokedastisitas}

Pengujian ini digunakan untuk mengetahui adanya ketidaksamaan varian dari residual suatu pengamatan terhadap pengamatan lainnya. Suatu model regresi seharusnya tidak terjadi heteroskedastisitas atau jika varian dari residual suatu pengamatan terhadap pengamatan lainnya adalah tetap. Pengujian ini menggunakan Uji Glejser yang digunakan untuk mengetahui apakah sebuah model regresi memiliki indikasi heterokedastisitas dengan cara meregresikan seluruh variabel independen terhadap absolut residualnya. Uji heteroskedastitas dinyatakan tidak terjadi jika nilai Signifikansi lebih besar dari nilai tingkat kepercayaan 5\%.

Apabila nilai signifikansi pada variabel Persepsi Kegunaan (Perceived Usefulness), Persepsi Kemudahan (Perceived Ease of Use), Persepsi Kepercayaan (Perceived Trust), dan Norma Subjektif (Subjective Norm)lebih dari 0,05 maka dapat dinyatakan tidak terjadi heteroskedastisitas. Berikut tabel hasil uji glejser menjelaskan hasil uji heterokedastisitas:

Tabel 5. Hasil Uji Heterokedastisitas

\begin{tabular}{|l|c|c|}
\hline \multicolumn{1}{|c|}{ Variabel } & Sig. & Keterangan \\
\hline Persepsi Kegunaan & 0.917 & Tidak terjadi heterokedastisitas \\
\hline Persepsi Kemudahan & 0.426 & Tidak terjadi heterokedastisitas \\
\hline Persepsi Keamanan & 0.153 & Tidak terjadi heterokedastisitas \\
\hline Norma Subjekti & 0.793 & Tidak terjadi heteroskedastisitas \\
\hline
\end{tabular}

Sumber: Hasil Pengolahan Data

Berdasarkan hasil uji heteroskedastisitas di atas, dapat disimpulkan bahwa masingmasing variabel memiliki nilai signifikansi lebih dari 0,05 sehingga dapat disimpulkan bahwa data tersebut dinyatakan tidak terjadi heteroskedastisitas.

\section{Uji Autokolerasi}

Pengujian ini bertujuan untuk mengkaji apakah suatu model regresi linier terdapat korelasi antara kesalahan penganggu pada periode $\mathrm{t}$ dengan kesalahan pada periode sebelumnya (t-1). Dalam hal ini uji autokolerasi menggunakan pendekatan uji Durbin-Watson. Uji Durbin-Watson dinyatakan tidak terjadi masalah autokolerasi jika d terletak diantara dU dan (4-dU) 
INOBIS: Jurnal Inovasi Bisnis dan Manajemen Indonesia

Volume 04, Nomor 02, Maret 2021

Celine Linardi, Triasesiarta Nur

Tabel 6. Hasil Uji Autokolerasi

\begin{tabular}{|l|c|c|c|c|c|}
\hline \multicolumn{7}{|c|}{ Model Sumarry $^{\mathbf{b}}$} \\
\hline Model & $\mathrm{R}$ & R square & $\begin{array}{c}\text { Adjusted } \\
\text { R Square }\end{array}$ & $\begin{array}{c}\text { Str. Error } \\
\text { of the } \\
\text { Estimate }\end{array}$ & $\begin{array}{c}\text { Durbin- } \\
\text { Watson }\end{array}$ \\
\hline 1 & $.691^{\mathrm{a}}$ & 0.477 & 0.455 & 1.970 & 2.171 \\
\hline \multicolumn{2}{|l}{ a. Predictors: (Constant), Kegunaan, Kemudahan Kepercayaan, Norma } \\
\hline
\end{tabular}

Sumber: Hasil Pengolahan Data

Berdasarkan tabel diatas, nilai Durbin-Watson yang didapat sebesar 2.171 lebih besar dari nilai tabel Durbin-Watson sebesar 1.758 dan kurang dari 2.241 yang didapat dari 4 - 1.758 $=2.241$. Maka dapat disimpulkan bahwa pada semua variabel tidak terjadi masalah atau gejala autokolerasi

\section{Pengujian Hipotesis}

Pengujian ini dilakukan untuk melakukan pembuktian hipotesis yang didasarkan pada penelitian yang sudah ada. Pengujian ini meliputi uji t, uji F dan koefisien determinan.

\section{Uji Parsial (Uji t)}

Uji statistik t dilakukan untuk menguji signifikasi hubungan antara variabel $\mathrm{X}$ dan variabel Y secara parsial atau dapat dikatakan uji t pada dasarnya menunjukkan seberapa jauh pengaruh suatu variabel bebas atau independen menerangkan variabel terikat atau variabel dependen secara individual. Dasar pengambilan keputusan dalam uji statistik t adalah dengan melihat nilai signifikansi dan melakukan perbandingan nilai t hitung.

Jika nilai signifikansi kurang dari 0,05 dan nilai t hitung lebih besar dari t tabel, maka Ha diterima. Ha diterima menunjukan bahwa variabel independen berpengaruh terhadap variabel dependen yang artinya variabel bebas berpengaruh terhadap variabel terikat.

Dan sebaliknya jika nilai signifikansi lebih dari 0,05 dan nilai t hitung lebih kecil dari t tabel, Ha ditolak. Ha ditolak menunjukkan bahwa variabel independen tidak berpengaruh terhadap variabel dependen, yang artinya varibel bebas tidak berpengaruh terhadap variabel terikat. Berikut adalah hasil pengolahan data SPSS untuk uji t:

Tabel 7 Hasil Uji t

\begin{tabular}{|c|c|c|c|c|c|c|}
\hline \multicolumn{7}{|c|}{ Coefficients $^{\mathrm{a}}$} \\
\hline \multirow{2}{*}{\multicolumn{2}{|c|}{ Model }} & \multicolumn{2}{|c|}{$\begin{array}{c}\text { Unstandardized } \\
\text { Coefficients }\end{array}$} & \multirow{2}{*}{$\begin{array}{c}\text { Standardized } \\
\text { Coefficients } \\
\text { Beta }\end{array}$} & \multirow[t]{2}{*}{$\mathrm{t}$} & \multirow[t]{2}{*}{ Sig. } \\
\hline & & B & Std. Error & & & \\
\hline \multirow[t]{5}{*}{1} & (Constant) & 4.172 & 1.272 & & 2.783 & 0.035 \\
\hline & Kegunaan & -0.445 & 0.087 & -0.194 & -.232 & 0.801 \\
\hline & Kemudahan & 0.717 & 0.152 & 0.382 & 4.722 & 0.036 \\
\hline & Kepercayaan & 0.393 & 0.106 & 0.355 & 3.715 & 0.041 \\
\hline & Norma & 0.531 & 0.111 & 0.377 & 4.801 & 0.015 \\
\hline \multicolumn{7}{|c|}{ a. Dependent Variable: MINAT } \\
\hline
\end{tabular}

Sumber: Hasil Pengolahan Data 


\section{Celine Linardi, Triasesiarta Nur}

Melalui hasil analisis maka penjelasan pengaruh masing-masing variabel bebas terhadap variabel terikat adalah sebagai berikut:

\section{Persepsi Kegunaan (Perceived Usefulness)}

Berdasarkan hasil pengujian yang telah dilakukan variable Persepsi Kegunaan tidak berpengaruh secara signifikan terhadap Minat mahasiswa berdonasi pada platform Crowdfunding. Hal tersebut ditunjukkan dengan diperolehnya nilai t-hitung sebesar (-0.232) dengan p-value sebesar 0.801 .

Persepsi Kegunaan merupakan sejauh mana seseorang percaya bahwa menggunakan suatu teknologi akan meningkatkan kinerja dari pekerjaannya (Chuang et al., 2016). Dengan adanya manfaat dari platform crowdfunding akan mampu meningkatkan kinerja bagi seseorang yang menggunakannya. Apabila kegunaan platform crowdfunding ditingkatkan maka akan diikuti meningkatnya minat menggunakan platform crowdfunding. Namun dalam hasil penelitian tidak sejalan dengan teori yang dikemukakan. Karena masih minimnya jumlah platform crowdfunding di Indonesia dan kurangnya sosialisasi dan branding dari pihak perusahaan platform crowdfunding untuk mempromosikan manfaat penggunaan platform-nya. Dari sisi pendanaan, mahasiswa melakukan donasi hanya sesuai kemampuan/keinginan yang mereka donasikan tanpa melihat apakah proyek crowdfunding yang sedang berjalan akan berhasil atau tidak.

Hasil penelitian ini tidak sejalan dengan penelitian (Bailey, Pentina, Mishra, \& Mimoun, 2017) yaitu variabel persepsi kegunaan berpengaruh secara signifikan terhadap minat penggunaan pembayaran melalui mobile payment. Namun penelitian ini sejalan dengan penelitian (Ramadhan, 2016) dimana persepsi Kegunaan tidak berpengaruh signifikan terhadap minat mahasiswa untuk menggunakan E-money.

\section{Persepsi Kemudahan (Perceived Ease of Use)}

Berdasarkan hasil pengujian yang telah dilakukan variable Persepsi Kemudahan berpengaruh secara signifikan terhadap Minat mahasiswa berdonasi pada platform crowdfunding. Hal tersebut ditunjukkan dengan diperolehnya nilai t-hitung sebesar 4.722 dengan $p$-value sebesar 0.036 .

Persepsi kemudahan merupakan keyakinan seseorang bahwa menggunakan sistem teknologi informasi tidak akan membutuhkan usaha yang besar dan juga tidak merepotkan pada saat penggunaan dan sebagai suatu tingatan dimana seseorang percaya bahwa teknologi informasi dapat dengan mudah dipahami (Aeni \& Purwantini, 2017). Persepsi kemudahan berpengaruh terhadap minat mahasiswa berdonasi menggunakan platform crowdfunding. Dalam hasil penelitian ini sejalan dengan teori yang dikemukakan. Semakin mudah penggunaan berdonasi pada platform crowdfunding maka akan semakin meningkatkan minat mahasiswa untuk berdonasi pada platform crowdfunding.

Penelitian ini sejalan dengan penelitian yang dilakukan oleh Patel \& Patel (2018) dimana variabel persepsi kemudahan berpengaruh terhadap minat menggunakan internet banking. Namun penelitian ini tidak konsisten dengan penelitian yang dilakukan oleh (Chong, Lin, \& Tan, 2010) yang menunjukkan bahwa persepsi kemudahan bukan merupakan faktor yang mempengaruhi minat menggunakan internet banking. 


\section{Persepsi Kerpercayaan (Perceived Trust)}

Berdasarkan hasil pengujian yang telah dilakukan variable Persepsi Kepercayaan berpengaruh secara signifikan terhadap Minat mahasiswa berdonasi pada platform crowdfunding. Hal tersebut ditunjukkan dengan diperolehnya nilai t-hitung sebesar 3.715 dan p-value sebesar 0.041 .

Persepsi Kepercayaan adalah kesediaan seseorang untuk menggantungkan dirinya pada pihak lain dengan risiko tertentu (Tjini \& Baridwan, 2013). Dalam hasil penelitian ini sejalan dengan teori yang dikemukakan. Seseorang yang sudah percaya dengan kinerja dan kemampuan platform crowdfunding akan memberikan kepercayaannya untuk mempunyai minat menggunakan. Semakin banyak kepercayaan masyarakat berdonasi pada platform crowdfunding, maka semakin tinggi minat mahasiswa berdonasi pada platform crowdfunding.

Penelitian ini sejalan dengan penelitian yang dilakukan oleh (Putra, 2014) yang menunjukkan variable Persepsi Kepercayaan berpengaruh terhadap minat menggunakan $E$ commerce. Namun penelitian ini tidak sejalan dengan penelitian yang dilakukan oleh (YC Chen $\&$ Sagynov, 2015) yang menunjukkan variable Persepsi Kepercayaan tidak terdapat pengaruh terhadap minat purchase online.

\section{Norma Subjektif (Subjective Norm)}

Berdasarkan hasil pengujian yang telah dilakukan variable Norma Subjektif berpengaruh secara signifikan terhadap Minat mahasiswa berdonasi pada platform crowdfunding. Hal tersebut ditunjukkan dengan diperolehnya nilai t-hitung sebesar 4.801 dengan $p$-value sebesar 0.015 .

Norma subyektif adalah pengaruh sosial yang mempengaruhi seseorang untuk berperilaku terhadap sikap tertentu (Mas'ud, 2012). Dalam hasil penelitian ini sejalan dengan teori yang dikemukakan. Seseorang akan memiliki keinginan terhadap suatu obyek atau perilaku apabila individu tersebut terpengaruh oleh orang-orang di sekitarnya untuk melakukannya atau meyakini bahwa lingkungan atau orang-orang disekitarnya mendukung terhadap apa yang lakukan. Semakin banyak norma - norma sosial di lingkungan masyarakat yang mendorong untuk berdonasi pada platform crowdfunding, makin semakin tinggi minat mahasiswa berdonasi pada platform crowdfunding.

Penelitian ini sejalan dengan penelitian yang dilakukan oleh (Y Chen et al., 2019) yang menunjukkan variable Norma Subjektif berpengaruh terhadap minat menggunakan online crowdfunding dan penelitian yang dilakukan oleh (Sari, 2019) berpengaruh terhadap minat menggunakan Peer-to-Peer $(P 2 P)$.

\section{Kesimpulan}

Penelitian ini bertujuan untuk mengetahui pengaruh persepsi kegunaan, persepsi kemudahan, persepsi kepercayaan, dan norma subjektif terhadap minat berdonasi pada platform crowdfunding pada di kalangan Mahasiswa yang berdomisili di Jabodetabek. Berdasarkan hasil peneltian dan pembahasan yang telah dilakukan, maka hasil yang diperoleh sebagai berkut:

1. Persepsi Kegunaan (Perceived Usefulness) berpengaruh tidak signifikan terhadap Minat berdonasi pada platform crowdfunding. Peneliti menyimpulkan bahwa mahasiswa belum memanfaatkan fitur platform crowdfunding secara maksimal, karena itu belum merasakan kegunaannya secara maksimal.

2. Persepsi kemudahan (Perceived Ease of Use) berpengaruh signifikan terhadap Minat berdonasi pada platform crowdfunding. Peneliti menyimpulkan, semakin mudah 
penggunaan berdonasi pada platform crowdfunding maka akan semakin meningkatkan minat mahasiswa untuk berdonasi pada platform crowdfunding.

3. Persepsi Kepercayaan (Perceived Trust) berpengaruh signifikan terhadap Minat berdonasi pada platform crowdfunding. Peneliti menyimpulkan, seseorang yang sudah percaya dengan kinerja dan kemampuan platform crowdfunding akan memberikan kepercayaannya untuk mempunyai minat menggunakan. Semakin banyak kepercayaan masyarakat berdonasi pada platform crowdfunding, maka semakin tinggi minat mahasiswa berdonasi pada platform crowdfunding.

4. Norma Subjektif (Subjective Norm) berpengaruh signifikan terhadap Minat berdonasi pada platform crowdfunding. Peneliti menyimpulkan, Seseorang akan memiliki keinginan terhadap suatu obyek atau perilaku apabila individu tersebut terpengaruh oleh orang-orang di sekitarnya untuk melakukannya atau meyakini bahwa lingkungan atau orang-orang disekitarnya mendukung terhadap apa yang lakukan. Semakin banyak norma - norma sosial di lingkungan masyarakat yang mendorong untuk berdonasi pada platform crowdfunding, makin semakin tinggi minat mahasiswa berdonasi pada platform crowdfunding.

\section{Daftar Pustaka}

Aeni, A. N., \& Purwantini, A. H. (2017). Eksplorasi Penggunaan Mobile Banking: Pendekatan Technology Acceptance Model. Jurnal Analisis Bisnis Ekonomi, 15(1), 86-96.

Ahmad, \& Pambudi, B. S. (2014). Pengaruh Persepsi Manfaat, Persepsi Kemudahan, Keamanan dan Ketersediaan Fitur Terhadap Minat Ulang Nasabah Bank Dalam Menggunakan Internet Banking. Jurnal Studi Management, 1(11).

APJII. (2019). Buletin APJII Edisi Maret 2019. Retrieved from ttps://apjii.or.id/content/utama/104

Bailey, A. A., Pentina, I., Mishra, A. S., \& Mimoun, M. S. B. (2017). Mobile payments adoption by US consumers: an extended TAM. Journal of Retail \& Distribution Management.

Charities Aid Foundation. (2018). CAF World Giving Index per Oktober 2018. Retrieved from https://www.cafonline.org/about-us/publications/2019-publications/caf-world-givingindex-10th-edition

Chen, Y, Dai, R., Yao, J., \& Li, Y. (2019). Donate time or money? The determinants of donation intention in online crowdfunding. Sustainability, 11(16), 42-69.

Chen, YC, \& Sagynov. (2015). Exploring factors that affect usefulness, ease of use, trust, and purchase intention in the online environment. International Journal of Management \& Information Systems (IJMIS), 19(1), 21-36.

Chong, A. Y. ., Lin, K. B., \& Tan, B. . (2010). Online banking adoption: an empirical analysis. International Journal of Bank Marketing.

Chuang, L. M., Liu, C. C., \& Kao, H. K. (2016). The adoption of fintech service: TAM perspective. International Journal of Management and Administrative Sciences, 3(7), 115.

Davis, F. D. (1989). Perceived Usefulness, Perceived Ease of Use and User Acceptance of Information Technology. MIS Quarterly, 13(3), 319-340.

Gomber, P., \& Koch, J. (2017). Digital Finance and FinTech: current research and future research directions. Journal of Business Economics, 87(5), 535-580.

Hossain, M., \& Oparaocha, G. O. (2017). Crowdfunding: motives, definitions, typology and ethical challenges. Entrepreneurship Research Journal, 7(2).

Jaziri, R., \& Miralam, M. (2019). Modelling the crowdfunding technology adoption among 
novice entrepreneurs: an extended TAM model. Entrepreneurship and Sustainability, 6(4), 2159-2179.

Lacan, C., \& Desmet, P. (2017). Does the crowdfunding platform matter? Risks of negative attitudes in two-sided markets. Journal of Consumer Marketing.

Lee, D. C. K., \& Teo, G. S. (2015). Emergence of FinTech and the LASIC Principles. Journal of Financial Perspectives, 3(3).

Mas'ud, M. H. (2012). Pengaruh Sikap, Norma-norma Subyektif dan Kontrol Perilaku yang Dipersepsikan Nasabah Bank Terhadap Keinginan Untuk Menggunakan Automatic Teller Machine (ATM) Bank BCA di Kota Malang. Jurnal Manajemen Dan Akuntansi, 1(3).

Moysidou, J., \& Hausberg, J. P. (2020). In crowdfunding we trust: A trust-building model in lending crowdfunding. Journal of Small Business Management, 58(3), 511-543.

Novitasari, I. (2016). Pengaruh Kecocokan, Persepsi Kegunaan, Persepsi Kemudahan dan Persepsi Kenyamanan Terhadap Minat Penggunaan e-money. Jurnal Ilmiah Mahasiswa $F E B, 3(2)$.

Nugroho, A. Y., \& Rachmaniyah, F. (2019). Fenomena Perkembangan Crowdfunding Di Indonesia. EkoNiKa, 4(1), 34-46.

OJK. (2017). FAQ: KATEGORI UMUM. Retrieved from https://ojk.go.id/id/kanal/iknb/datadan statistik/direktori/fintech/Documents/FAQ Fintech Lending.pdf

Patel, K. J., \& Patel, H. . (2018). Adoption of internet banking services in Gujarat. International Journal of Bank Marketing.

Priambodo, S., \& Prabawani, B. (2016). Pengaruh Persepsi Manfaat, Persepsi Kemudahan Penggunan, Dan Persepsi Risiko Terhadap Minat Menggunakan Layanan Uang Elektronik (Studi Kasus Pada Masyarakat Di Kota Semarang). Jurnal Ilmu Administrasi Bisnis, 5(2), 127-135.

Putra, A. (2014). Pengujian Personal Financial Behavior, Planned Behavior terhadap Self Control Behavior Dengan Theory Planned of Behavior. Jurnal Ilmiah Wahana Akuntansi, 9(1), 1-19.

Rahmad, A. D., \& Astuti, E. S. (2017). Pengaruh kemudahan terhadap kepercayaan dan penggunaan sms banking. Administrasi Bisnis, 36-43.

Ramadhan, A. F. (2016). Persepsi Mahasiswa Dalam Menggunakan E-money. Jurnal Dinamika Ekonomi \& Bisnis, 13(2).

Samudra, T. B., Maslichah, M., \& Sudaryanti, D. (2020). Pengaruh Sikap, Norma Subjektif, dan Kontrol Keperilakuan yang dipersepsikan terhadap Kepatuhan Wajib Pajak Orang Pribadi di Kota Batu. Jurnal Ilmiah Riset Akuntansi, 9(1).

Sari, A. P. (2019). Pengaruh Brand Awareness, Kualitas Proyek Dan Kepercayaan Terhadap Keputusan Berdonasi Secara Online Pada Platform Crowdfunding Kitabisa.Com. Universitas Islam Negeri Sumatera Utara.

Schwienbacher, A., \& Larralde, B. (2010). Crowdfunding of small entrepreneurial ventures. Handbook of entrepreneurial finance, Oxford University Press.

Shneor, R., \& Munim, Z. H. (2019). Reward crowdfunding contribution as planned behaviour: An extended framework. Journal of Business Research, 103, 56-70.

Sugiyono. (2016). Metodologi Penelitian Kuantitatif, Kualitatif, dan R\&D. Bandung: CV Alfabeta.

Tjini, S. S. A., \& Baridwan, Z. (2013). Pengaruh Kepercayaan. Persepsi Kegunaan, Persepsi Kemudahan, and Persepsi Kenyamanan Terhadap Minat Penggunaan Sistem Internet Banking. Jimfeb.Ub.Ac.Id, 1-21.

Yu, P. L., Balaji, M. S., \& Khong, K. W. (2015). Building trust in internet banking: a trustworthiness perspective. Industrial Management \& Data Systems. 